\title{
THE NOBEL LECTURE GIVEN BY The Nobel Peace Prize Laureate $1996 *$
}

\section{José Ramos-Horta}

Suas Majestades, Honoráveis Membros do Comité Nobel da Paz, Senhores Presidentes, Primeiros Ministros, Excelências:

Com vossa permissão as minhas primeiras palavras serão na língua de Camões, Fernando Pessoa, Agostinho Neto, Jorge Amado, Xanana Gusmão.

Apesar da brutal colonização indonésia e da repressão cultural dos últimos 21 anos, da proibição de uma língua e cultura que chegaram á nossa região há cerca de 500 anos, em Timor Leste esta língua secular ainda persiste teimosamente.

Sendo o segundo timorense de nacionalidade portuguesa a ser honrado com o Prémio Nobel de Paz, o primeiro é o nosso respeitado e venerado bispo Dom Carlos Filipe Ximenes Belo, faltaria à minha herança histórica e consciência se não começasse esta minha intervenção na língua que hoje une mais de 200 milhões de pessoas nas cinco regiões do mundo.

É com um profundo sentimento do humildade que me associo aqui a Dom Carlos Filipe Ximenes Belo para receber o Prémio Nobel de Paz 1996 que foi outorgado ao povo de Timor Leste.

Registo a minha eterna gratidão àqueles que me propuseram para este prémio. Estou-lhes para sempre moralmente endividado e asseguro que as modestas dádivas de saúde e inteligência que Deus me deu serão sempre postas ao serviço da paz e justiça para o meu povo e para a causa da paz, liberdade e democracia em todas as latitudes onde a minha fraca voz possa ser ouvida.

\footnotetext{
"Reprinted with permission. Copyright (c) The Nobel Foundation, Stockholm, 1996.
} 
162 José Ramos-Horta

Apenas por razões práticas vou continuar a minha intervenção na língua inglesa. I will now speak in English.

Your Majesties, Honorable Members of the Nobel Committee, Presidents, Prime Ministers, Excellencies:

With your permission my first words will be in the language of Camões, Fernando Pessoa, Agostinho Neto, Jorge Amado, and Xanana Gusmão.

In spite of the brutal Indonesian colonization and cultural repression of the past twenty-one years that have attempted to eradicate a language and culture that reached our region almost five hundred years ago, in East Timor this rich centuries-old language survives stubbornly.

Being the second East Timorese of Portuguese nationality to be honored with the Nobel Peace Prize (the first is our respected and reverend bishop Carlos Filipe Ximenes Belo), I would be failing my own historical heritage and conscience if I were to start this Nobel lecture in another language other than in the language that unites more than two hundred million people in the five regions of the world.

It is with a deep feeling of humility that I join today with bishop Carlos Filipe Ximenes Belo to receive the 1996 Nobel Peace Prize that has been bestowed on the people of East Timor.

My eternal gratitude to those who nominated me. I am forever morally indebted to them, and I can assure them that God's modest gifts of health and wisdom to me will always be put to the service of peace and justice not only for my country and people but also for the cause of peace, freedom, and democracy in every place where my faint voice can be heard.

My deepest appreciation goes to the Nobel Committee for having chosen us for the 1996 Nobel Peace Prize. Your generosity in thinking of the wretched of the earth, and your courage in standing up to the might of States, the cynicism and indifference of too many, betrayal by some, tells also a lot about the soul and history of courage of this great country of yours that fought bravely during World War II.

In recent years Norway has played a central role in fostering dialogue and peace among historical enemies. In the Middle East and Central America, your discreet nature, determination, and creativity have proven that some of the world's seemingly intractable conflicts can be resolved when there is an honest mediator and when the parties in conflict are willing to end the war.

Small countries like Norway, Costa Rica, and Portugal, and others, can succeed in mediating conflicts when mighty powers have failed. Diplomacy and mediation are not prerogatives of the major powers. The small and medium-sized countries without ambitions to a neo-imperial role, whose strength is their moral integrity, are best placed to open dialogue among the parties in conflict.

\section{The East Timorese Church}

The real winner of the 1996 Nobel Peace Prize is our spiritual leader, Dom Carlos Filipe Ximenes Belo. He is the embodiment of the East Timorese people's resilience, moral rectitude, dignity, and identity, and its long quest for peace and freedom. In 
Dom Carlos the people of East Timor have found spiritual comfort and some sense of security from the daily threats to their very existence.

The people of East Timor owe almost everything to their church. Hence, the 1996 Nobel Peace Prize is a tribute to the whole church, the courageous priests, nuns, and lay workers, and the people of East Timor.

My share of the Nobel Peace prize will go entirely to a foundation to be called Peace and Democracy Dom Martinho da Costa Lopes. I know this is too small a tribute to this great man who gave his life to the church and people.

\section{The solidarity movement}

I would also like to express my gratitude to three organizations that in the past honored my people with less well-known awards but with equal importance for our people. To Professor Thorof Rafto Human Rights Foundation from Bergen, Gleitsman Foundation, from California, and the Un-Represented Nations and Peoples Organization (UNPO) based in the Hague, goes my profound gratitude.

With the men, women and children in many parts of the world who have given us so many years of their lives I wish to share this moment of joy. Without the generous solidarity movement we would be even poorer and alone. Some of our good friends have passed away from this earth: Denis Freney, Michelle Turner, Michel Robert, Carlos Vilares, the little and beautiful Sarah Taylor whom God took away at age fifteen. We will remember them forever.

\section{Angola, Cape Verde, Guinea-Bissau, Mozambique, São Tomé and Príncipe}

My special greetings of friendship and eternal gratitude to my good friend, President Joaquim Chissano of Mozambique, for having taken the trouble to fly to Olso to be with us.

You have been with us in our most lonely years when the rest of the world pretended we did not exist or offered us advice on how best to surrender. From this noble rostrum I bow to your late predecessor, Samora Moisés Machel, one of the greatest men Africa has ever known.

My special greetings and deepest gratitude to Presidents José Eduardo dos Santos of Angola, Mascarenhas Monteiro of Cape Verde, Nino Vieira of Guinea-Bissau, and Miguel Trovoada of São Tomé and Príncipe for their friendship and generosity.

Your peoples and countries have been with us through our lonely years and I believe that you will be with us still in the years to come.

To the people of Angola who have suffered beyond imagination and are still in a painful process of national reconciliation, I extend our solidarity and friendship.

Angola paid a heavy price for the liberation of Namibia and South Africa. Yet there has not been enough recognition of the enormous contribution that the two Iusophone countries, Angola and Mozambique, gave to the liberation of Southern Africa. 
164 José Ramos-Horta

\section{Portugal}

I wish to express from this august rostrum the eternal gratitude of the people of East Timor and my own gratitude to the people of Portugal, the President, our good friend Dr. Jorge Sampaio and his predecessor, Dr. Mário Soares, a man of principles and compassion.

Through Your Excellency, Mr. President, I humbly ask you to convey to your wonderful and generous people, members of Parliament and government, past and present, our most heartfelt appreciation for your gallant efforts in support of our struggle.

For many years you fought a lonely battle in the European Union against the indifference and even hostility of some of your partners. You have shown not only to us East Timorese but to other smaller nations in the world that principles and morality have not been taken over completely by mercantile interests.

\section{Brazil}

I recently visited Brazil and was warmly welcomed by everyone. I humbly ask President José Sarney to convey to President Fernando Henrique Cardoso and through him to all the people of Brazil our admiration and affection for your great country and people. My warmest greetings to Betinho, Dom Paulo Evaristo, and Dom Hélder Cãmara, the conscience of the poor of Brazil and the world.

Your Majesties:

This speech belongs to someone else who should be here today. $\mathrm{He}$ is an outstanding man of courage, tolerance, and statesmanship. Yet, this man is in prison for no crime other than his ideas and vision of peace, freedom, and the dignity of his people.

Xanana Gusmão, leader of the people of East Timor, remains incommunicado in a prison thousands of miles from his country. His trial in 1993 was universally condemned as a charade and was no more valid than the Dutch imprisonment and trial of the late President Sukarno, founding father of the Indonesian Republic.

I bow to Xanana and through him to my good friend Nino Konis Santana, David Alex, Tahur Matan Ruak, Fernando Araújo, and all East Timorese prisoners of conscience in jails in East Timor and Indonesia, to the thousands of victims of torture, widows and orphans. I bow to the memory of Sabalae and the thousands of our dead.

Through Xanana, I bow to my people with profound respect, loyalty, and humility because they are the martyrs, the real heroes and peace-makers.

\section{The New Order regime and the Indonesian people}

The East Timorese are not the exclusive victims of the Indonesian New Order regime installed in 1965 . For more that thirty years, the Indonesian people have known massacres, imprisonment, torture, bans on writers, journalists, academics, and labor leaders. Moslems, Catholics, Buddhists, and Hindus have all known their share of repression. The only non-discriminatory policy of the New Order Regime is when it comes to repression. 
I pay tribute to the many tens of thousands of Indonesians who died in their own struggle for freedom and democracy, who languished in the jails of the New Order, or who were forced into exile in China, Albania, the USSR, and Western Europe. I met many of them over the years and shared long hours of conversation about our two peoples' suffering and dreams.

\section{The lessons of the Jewish holocaust}

In 1939, a few months before the outbreak of World War II, Harry Truman read a passionate message from President Roosevelt to the "National Meeting for Moral Rearmament" held in Washington.

The same time as the conference delegates were listening and applauding President Roosevelt's moral speech, nine hundred Jewish refugees on a boat from Germany anchored off Florida were waiting for a decision from Washington as to whether they should find sanctuary in the US or be sent back.

Finally word came that their application for refugee status had been denied. The desperate refugees did not conceive the morally courageous delegates to the "National Meeting for Moral Rearmament" that they had a valid fear of persecution. The nine hundred men, women, and children were sent back to Germany. Many ended up in Hitler's death camps.

More than half a century after the Jewish holocaust and centuries after the genocide of the indigenous peoples of Australia and the Americas, the same attitude that has allowed these crimes to take place persists today.

Opinion-makers and leaders, academics, writers, and journalists who pretend to be objective and neutral in the face of racism and discrimination, the rape of a small nation by a larger power, the persecution of a weaker people by a ruthless army, must share the guilt. No amount of intellectual argument will suffice to erase their responsibility.

Synagogues are still being desecrated. Gypsies are still discriminated [against]. Indigenous peoples continue to see their ancestral lands taken over by developers, their culture and beliefs, and their very existence reduced to a tourist commodity.

Like the Jews and Armenians in the past, like Kurdish, Gypsies, Tibetans, Aborigines of Australia, Maoris of Aotearoa (New Zealand), Kanakis of New Caledonia, the people of Western Sahara, and the indigenous peoples of the Americans, the East Timorese are a mere footnote of history, an expendable people.

\section{Cold War footnote}

The conflict in East Timor can be traced back to the political context of the Cold War.

You might recall a picture that made headlines in the spring of 1975 . I refer to the picture of an American helicopter landing on the rooftop of the US Embassy in Saigon to rescue remaining diplomats, CIA operatives, and a few privileged South Vietnamese stooges as Saigon fell to the Vietcong. Cambodia and Laos followed. The picture illustrated better than a thousand words the ignominious American retreat from Indochina. 
166 José Ramos-Horta

In another continent, in the horn of Africa, the longest reigning US ally, emperor Hailé Selassié of Ethiopia, had been overthrown a year earlier by radical army officers. Further south, the Portuguese empire had collapsed. These events seemed to confirm Lyndon B. Johnson's domino theory which was the rationale for US intervention in Indochina.

It was in this geopolitical context that President Gerald Ford and his Secretary of State, Henry Kissinger, visited Jakarta in early December 1975 as part of an Asian tour to reassure leaders of the region that the US would continue to honor its security commitments in Asia.

The invasion of East Timor which took place within hours of Ford's departure from Jakarta was a mere footnote in the Cold War events of 1975. Thousands of East Timorese who died in the days, weeks, months, and years that followed were mere footnotes to the post-Vietnam and Cold Wars.

\section{Inviolability of colonial boundaries}

One and a half years before these events, in June 1974, I visited Jakarta in my capacity as secretary for Foreign Affairs of the Timorese Social Democratic Association, that just been created less than a month earlier. I had the privilege of meeting with the then Foreign Minister of Indonesia, Mr. Adam Malik. After our third round of talks, Mr. Malik addressed me a letter which read in part:

The independence of every country is the right of every nation, with no exception for the people of (East) Timor;

... whoever will govern in Timor in the future after independence can be assured that the government of Indonesia will always strive to maintain good relations, friendship, and co-operation for the benefit of both countries.

The following year, in April 1975, I again visited Indonesia and met with President Suharto's senior advisor, Gen. Ali Murtopo, to whom I reiterated our collective desire to develop friendly relations with Indonesia. Gen. Murtopo reassured me that Indonesia harbored no territorial ambitions over East Timor. However, we soon learned that the word of an Indonesian general or diplomat can be broken as easily as it can be spoken.

Some simple but fundamental issues need to be addressed. Does Indonesia have a valid historical claim to East Timor?

The current boundary of the Republic of Indonesia is a product of the Dutch East Indies administration. West New Guinea was absorbed by the Republic not because of a reasonable historical, cultural, ethnic kinship, or geographic continuity. The only link that justified the annexation was West New Guinea's brief colonization by the Dutch.

The arbitrary carving up of Africa at the Berlin Conference can be blamed for some of Africa's problems today, but respect for the colonial boundaries, as unfair as most might be, has provided some peace and stability and kept most of Africa, Latin America, and Asia from disintegrating.

Saddam Hussein of Iraq attempted to redraw the map and rectify what he perceived to be an unfair colonial legacy by invading Kuwait. Iran has long-standing 
claims over Bahrain. In Latin America there are some inter-state territorial disputes as a result of perceived unfair boundary delimitation.

\section{The right of peoples to self-determination}

From the Chittagon Hill Tracts in Bangladesh to Bougainville, Kurdistan, Sri Lanka, India, Tibet, Chechnya, Ogoni, West Papua, millions of people seek to assert their most fundamental rights, and if we attempt to find a common denominator for the problems I have just listed there is one: the right of peoples to self-determination.

In most cases the demands are not for secession. They are about their survival as a people with a language and a culture. With their land and environment protected from rapacious multinationals. Only when these basic demands are not met has there been recourse to other forms of struggle, with an escalation in their demands.

While self-determination in the de-colonization process of the non-self-governing territories almost always led to independence, this is not the case in most of the conflicts of today. The cases of Western Sahara and East Timor are the two most salient failures of decolonization. In the case of Western Sahara, the United Nations has allowed itself to be pawn [moved by] the machinations of a minor regional power.

However, the preservation of the territorial integrity of a country can be achieved only if those in power are sensitive to the basic demands and aspirations of the many indigenous peoples and nationalities that make up the country.

Brute force might silence and keep dormant the dreams and aspirations of a people, but the anger simmering for decades will inevitably resurface and break up the country.

\section{The right of the people of East Timor to self-determination}

The right of the people of East Timor to self-determination is widely recognized. Apart from the former Spanish territory of Western Sahara, East Timor is the largest non-self-governing territory in the UN GA decolonization list which dates back to 1960.

The UN General Assembly and Security Council have adopted a total of ten resolutions on the question of East Timor all reaffirming this right.

In its ruling of 30 June 1995 on the Case Concerning East Timor, Portugal vs. Australia, the International Court of Justice stated that the right of self-determination has an erga omnes character and that the people of East Timor are entitled to it.

\section{Dialogue without pre-conditions and the CNRM Peace Plan}

The Israeli-Palestinian peace talks and South Africa's transition to democracy give us renewed hope in that they demonstrate that seemingly intractable problems can be resolved if there is political will and vision by all involved.

In this room today there are East Timorese leaders of every persuasion, some who have come all the way from East Timor, Portugal, and Australia, and I can speak for all when I say that we are ready to enter into a process of dialogue with the Indonesian authorities, under the auspices of the United Nations, without pre-conditions, to explore all possible ideas towards a comprehensive settlement of the conflict. 
168 José Ramos-Horta

In 1992, after thorough consultation with other people in the country, Xanana Gusmão gave his seal of authority to what is now known as the CNRM Peace Plan which was formally presented to a meeting of the European Parliament in Brussels on 22 April 1992.

The CNRM proposal remains valid as a modest contribution towards finding a solution to the conflict.

\section{Phase One-Humanitarian phase}

This phase, which should take up to two years to be fully implemented, would involve all three parties working with the UN to implement a wide range of "confidence building measures" (CBMs), but would not deal with the core of the problem which is the issue of self-determination.

These CBMs must include the release of all prisoners, the end of torture and summary executions, and a drastic reduction in Indonesia troop presence in the territory.

These are some of the ideas which I believe could be implemented immediately without loss of face for Indonesia. Its international standing would improve significantly, and its presence in the territory would be less resented, thus relieving a very tense situation.

In view of the time restraints, the full text of this plan is attached to this speech.

Phase Two-Autonomy, five years

Phase two, lasting between five to ten years, would be a period of genuine political autonomy based on ample powers vested in a local, democratically elected Territorial People's Assembly.

At the end of the second phase, the autonomous status of the territory could be extended by mutual accord.

The East Timorese people, having enjoyed a period of peace and freedom without the presence of the most hated symbol of the occupation, the army, might accept to continue this form of association.

Conversely, the changing generation, attitudes and perception in Indonesia might result in Indonesia accepting as natural that East Timor becomes independent.

\section{Phase Three-Self-determination}

If all parties agree that Phase Three should enter into effect immediately, then the UN begins to prepare a referendum on self-determination to determine the final status of the territory.

If, God willing, East Timor becomes independent, ladies and gentlemen allow me to share with you our vision of our country's future and role in the region.

\section{Our vision for the future}

East Timor is at the crossroads of three major cultures: Melanesian which binds us to our brothers and sisters in the South Pacific region; Malay-Polynesian binding us to Southeast Asia; and the Latin Catholic influence, a legacy of almost five hundred years 
of Portuguese colonization. This rich historical and cultural existence places us in a unique position to build bridges of dialogue and co-operation between the peoples of the region.

\section{Portugal}

East Timor will maintain close ties with Portugal, [for this] country which colonized us for almost half a millennium has shown an abiding commitment to our right to self determination. Portugal and East Timor will be most valuable partners for ASEAN in its relations with the EU, Africa, and Latin America.

\section{Australia and South Pacific}

The majority of East Timorese residents outside the country are in Australia. In spite of our sadness over Australia's role on East Timor, I wish to state here our deepest appreciation to Australia for the shelter, hospitality, and generosity shown to our thousands of refugees on Australian soil.

We appreciate the many representations the previous and current governments of Australia have made to impress upon the government of Indonesia regarding the human rights situation in East Timor. No other Western country has been more persistent in this regard.

We fought together during World War II and many East Timorese gave their lives for our common cause. Now and in the future we look up to Australia for help. An independent East Timor will seek close relations with Australia and membership in the South-Pacific Forum.

\section{ASEAN and APEC}

We are conscious of our geography which compels us to co-exist with our neighbors in that part of the world. We will seek membership in ASEAN and APEC within days of independence.

\section{A Zone of Peace}

We will not have a standing army. For our external security, we will rely on a Treaty of Neutrality to be guaranteed by the permanent members of the Security Council. We will endeavor with the UN and our neighbors to declare our region and the seas surrounding East Timor a Zone of Peace and Development.

\section{Rule of Law}

We will endeavor to build a strong democratic state based on the rule of law which must emanate from the will of the people expressed through free and democratic elections.

\section{Human rights and international obligations}

All international human rights treaties will be submitted to the Parliament for ratification.

We believe that human rights transcend boundaries and must prevail over state sovereignty. 
170 José Ramos-Horta

We will introduce into the school curriculum at an early stage starting in the kindergartens the subject of human rights.

We will actively work with like-minded countries, NGOs, and the media to strengthen the UN human rights machinery.

\section{Amnesty and national reconciliation}

East Timorese now serving in the Indonesian administration in East Timor, the security forces, and the police should not fear an independent East Timor. They will be invited to stay on. Their full active involvement in running the country will be necessary to insure a smooth transition.

Our society will not be based on revenge. Because of its credibility and standing, the Catholic Church will be expected to play a major role in the healing process of our society.

In August 1975 too many East Timorese died in a brief but violent civil strife. Many more died even after the invasion because some in the leadership of the movement [to which] I belonged took upon themselves the role of judges and executioners.

\section{National reconstruction and development}

East Timor is a relatively small country. But with an area of 18,899 square kilometers and a total population of seven hundred thousand (1974 figures), it is at least equal to, if not larger in size and population, than some forty independent states. It is potentially self-sufficient in most agricultural goods, meat, and fish. It has large reserves of oil, natural gas, marble, and manganese.

The invasion uprooted thousands of people. Properties were abandoned, destroyed, or sold at unfair prices. This situation will be redressed. A voluntary resettlement plan will be effected to allow the many tens of thousands of displaced East Timorese to return to their ancestral lands. We believe in free education and health care for our people. The money saved from not having a standing army will be used in these areas. With the co-operation of WHO we will seek to eradicate malaria, tuberculosis, and other preventable diseases within a decade.

\section{Indonesian migrants}

It is estimated that over one hundred thousand Indonesians are now living in East Timor. Most are poor Indonesians who came to our country looking for a better life.

Indonesian migrants in East Timor will be welcome to stay.

\section{The Suharto regime, its achievements and what it should do}

No one can honestly suggest that the thirty-year regime of Gen. Suharto has not done good for Indonesia. The record of the past twenty years has been impressive. The Suharto regime lifted the Indonesian economy from extreme poverty to the status of an economic tiger. Living standards, literacy, health care, and food production increased to impressive levels.

President Suharto can show leadership by releasing all prisoners, meeting Indonesia's greatest living author, Pramoedya Ananta Toer, Megawati Sukarnoputri, leader of the PDI, daughter of Indonesia's founding father, the late Bung Karno, 
Muchtar Pakpahan, Indonesia's Lech Walesa, Sri Bintang, and George Aditjondro, Indonesia's most decorated environmentalist.

Suharto should talk and listen to the wise and most respected Moslem scholar Abdurramanh Wahid who is here today with us in Oslo.

The leaders and militants of the PRD are among the best children of Indonesia. Instead of hunting them he should invite them to his palace for dialogue about the future.

\section{Fostering a democratic and peaceful transition in Indonesia}

No country no matter how rich and endowed with natural resources, is an island into itself. In an increasingly smaller world and competitive age, where modern electronic communications break the barriers of silence erected by dictators, Indonesia cannot continue to flout the right of the people of East Timor to self-determination and the rule of law in Indonesia.

The next two or three years will witness a transition in Indonesia. Australia, New Zealand, the US, Canada, and the EU can encourage a peaceful, evolutionary transition with a discreet yet firm policy of pushing for democratic reforms and the rule of law in Indonesia and for a genuine act of self-determination in East Timor.

\section{The role of the international community}

We are as determined as we are optimistic about our future. To Indonesia and our neighbors in the ASEAN we are offering a hand of friendship and appealing to them to help us bring peace and freedom to East Timor.

The EU, working with the US, Canada, Australia, New Zealand, Japan, and Indonesia's partners in the ASEAN, can accelerate the ongoing dialogue under the auspices of the UN secretary-general, give it some impetus and real substance.

The US Administration is the only major power that has adopted some concrete measures to encourage changes in Indonesia and East Timor. I express here our sincere appreciation to President Clinton for his actions on East Timor, and I appeal to him to lend his youthful energy and compassion towards a permanent resolution of the conflict which he once described as "unconscionable."

\section{The West and arms sales}

We are not asking that Indonesia be punished with comprehensive economic sanctions. We believe that economic engagement with a country can at times foster positive changes through the development of democratically conscious class.

However, we find it repulsive that the Western countries that more loudly make rhetorical speeches about human rights are the ones that manufacture the most weapons that have killed more than twenty million people in the developing world since World War II.

Land mines, torture equipment, cluster bombs, chemical weapons and weapons designed to inflict pain and death on human beings. Most victims are civilians, women, and children. How can arms manufacturers, weapons designers, plant managers, politicians, whom have families of their own whom they love, be so insensitive when it comes to the suffering of other human beings? 


\section{Human rights and "Asian values"}

The peoples of Burma, Thailand, the Philippines, South Korea, and the democracy movements in China and Indonesia are telling the rest of the world that democracy and human rights are not an invention of the West.

The thousands of Asians who died in the streets of Manila, Bangkok, Jakarta, Rangoon, Beijing, did not die for so called "Asian value" that denies the people of Asia the basic and fundamental freedoms enjoyed by Europe, Latin America, and an increasing number of countries in Africa.

\section{South Korea}

The brave people of Korea who endured decades of dictatorship and occupation won the struggle for democracy not with guns but with their tenacity in fighting the troops in the streets of Seoul and Kwangju.

The South Korean People can also show greater courage by being magnanimous and forgiving those who have done wrong. Sometimes in history individuals in power are

driven to commit wanton crimes, but those who survive and are in power today should resist the temptation to exact revenge in the name of justice.

The death sentence must be abolished and the brave people of Korea should set the example of commuting the sentence on former President Chun Do Hwan. From here I appeal to my Korean friends not to exact revenge against those who have been defeated. In victory be magnanimous.

\section{Burma}

I extend our most heartfelt solidarity to the people of Burma and their elected leader, Nobel Peace Laureate Daw Aung San Suu Kyi, in their struggle for democracy, the rule of law, and human rights.

At a time when some ASEAN rulers are conniving with the SLORC regime to deny the people of Burma their democratic victory, we must all stand up and redouble our efforts to restore democracy to Burma.

The US and the EU must be commended for their leadership in support of the restoration of democracy in Burma, but they must escalate the pressure with additional diplomatic and economic sanctions against the SLORC.

I also fully endorse the recommendations on Burma adopted by the Forum of Democratic Leaders in the Asia Pacific led by Kim Dae Jung and Cory Aquino in their recent meeting in Manila.

\section{China, Taiwan, Tibet}

When the UN SC debated the issue of East Timor in 1975 and 1976, China was our closest ally and I worked closely with very able Chinese diplomats. In spite of the indifference of our four permanent members, China, along with other non-permanent members, succeeded in pushing the SC to adopt two resolutions on East Timor.

It is with this feeling of gratitude and admiration for China that I appeal to the Chinese leaders to listen to their own people's opinions and desires for a more open society, based on the rule of law, democracy, and freedom of speech. These are, after all, rights that are granted to each Chinese citizen by their own Constitution. 
Wei Jing Zhen is one of China's best children. He is being wasted away when his talents could best be used in the service of his fellow Chinese people and country.

The people of Taiwan have shown great maturity, responsibility, and commitment to peace and democracy. While there is no dispute that Taiwan is part of China, as long as there is no progress on the issue of peaceful renunciation of the two countries, I believe that the cause of dialogue and peace can best be served if Taiwan is granted observer status in the UN, as was the case in the past with South Korea, South and North Vietnam. After all, China has not objected to Taiwan and Hong Kong joining the APEC.

China should listen to the voice of peace and moderation of the Tibetan people. For many years the Tibetan spiritual leader, His Holiness the Dalai Lama, has offered a moderate peace proposal to the Chinese authorities to settle the Tibetan conflict.

\section{Cyprus}

Cyprus, a shining example of democracy and tolerance, remains divided and occupied by a NATO ally whose history of aggression and violence is well-known.

Recently I received a letter signed by the students of Classes C11 and C22 of Kykko B Lyceum in Nicosia who wrote:

Your homeland is an occupied country at the far end of the ocean. Our homeland lies partly occupied at the far end of the Mediterranean. We live in a divided city and we cannot cross the dividing line...

To the students of Kykko B Lyceum I can only say that like the ancient Armenia you too will recover your lost land.

\section{The prophets of doom}

The world has changed dramatically over the past few years, and the theorists of irreversibility and the status quo have been discredited by the collapse of the USSR.

Who would have thought it possible that the great Armenian people, persecuted for hundreds of years, would regain a country called Armenia?

The entire world conspired against the Eritrean people. Americans, Russians, and Cubans all connived against that small nation.

Two great nations, [peopled by] Israelis and Palestinians, who swore eternal hatred have shown courage and wisdom and begun a painful process of dialogue.

In South Africa former enemies are trying to rebuild their former home.

Last but not least, for the prophets of doom, for those in government who counsel us [in] "realism," allow me to remind them of a news item in the ever reliable BBC a few years ago.

It was sometime in 1991, and I was driving from the small Swiss town of Nyon, to the Palasis des Nations in Geneva, to yet another round of futility in a place where some diplomats pretend to be too busy to listen to real problems of real peoples.

The $\mathrm{BBC}$ was telling us a story of a Soviet cosmonaut who had gone into space a few months earlier on one of those record-breaking missions in space. When he was 
174 José Ramos-Horta

blasted off from somewhere in the Soviet Union, he carried a passport and a nationality granted to him by the most feared military empire in the world.

Once he completed his tour of duty for the pride of the socialist motherland, he prepared the spacecraft for its return voyage to earth. But he no longer had a country to return to. The mighty empire had ceased to exist. He was forced to circle the earth a few days longer until people of good will on earth decided which country he should go to.

With this note, I will end with renewed hope that no matter the level of brute force used against us, our dreams will never die.

God bless you all. Thank you.

\section{Appendix}

The CNRM Peace Plan

Phase One (one to two years to be implemented)

The CNRM does not pretend that this plan is the only blueprint for a peaceful resolution of the East Timor conflict. However, it believes that at least it can be the basis for discussion by all parties.

This phase of the talks must focus on achieving:

* Immediate end to all armed activities in East Timor;

* Reduction of Indonesian troop presence to a maximum of one thousand within a six month period;

* Removal of all heavy weapons, tanks, helicopters, combat aircraft, long-range artillery;

* Immediate and unconditional release of all political prisoners;

* Reduction by 50 percent of all Indonesian civil servants in East Timor;

* Stationing in the territory of UN Specialized Agencies such as UNICEF, UNDP, $\mathrm{WHO}$, and $\mathrm{FAO}$;

* A comprehensive census of the population;

* Establishment of an independent Human Rights Commission under the Catholic Bishop;

* Lifting of all media control by the army;

* Freedom of political activities;

* Removal of restrictions on the teaching of Portuguese; a Portuguese Cultural Institute is set up;

* Appointment of resident Representative of the UN Secretary-General.

Phase Two - Autonomy phase (five to ten years)

Full implementation of phase one is a prerequisite for the successful implementation of phase two.

Elections for a Territorial Assembly will be free and fair only if they are conducted after the full implementation of phase one. 
The following must be implemented in the second phase:

* Political parties, including those advocating independence for East Timor, are legalized;

* The EU sets up a legation in East Timor headed by a senior Portuguese official;

* Elections are held for a Territorial Assembly. The UN to provide technical support and supervision of the entire process;

* Only Timorese identified as such may vote and are eligible;

* The Assembly elects a Governor of the Territory;

* The Assembly and the Governor have a five-year mandate;

* The Territory may enter into trade relations with foreign countries, promulgate its own laws and affecting investment, land ownership, property, immigration, etc.;

* Remaining Indonesian troops are withdrawn within three months;

* The Territory will have no army. A police force is trained by the UN and is placed under the elected governor;

* Further reduction of Indonesian civil servants;

* Portugal and Indonesia normalize relations.

The second phase can be extended only if a two-thirds majority of the Assembly deputies vote for such an extension and this recommendation has been put to a referendum.

This referendum is a safeguard for the people since there is no guarantee that the Territorial Assembly members will reflect the true sentiments of the people on such a critical issue.

It is obvious that if this referendum results in a majority rejection of the extension of the autonomy status, the implication will be that the people will reject integration in Indonesia.

\section{Phase Three (referendum on self-determination)}

If the Territorial Assembly rejects an assembly of the autonomy phase, or if the Assembly votes in support of the extension but this vote is rejected in a referendum, then the final status of the territory is resolved.

A UN-supervised referendum is held on the three options provided for in the UN GA Res. 1514 (XV) of 15 December 1960: Independence, free association (with the colonial power of Portugal) or integration with another independent state (Indonesia).

A referendum must be held within one year of the end of Phase Two. 